\title{
EKSPLORASI METAKOGNISI TERHADAP PEMECAHAN MASALAH MATEMATIKA DITINJAU DARI GAYA BELAJAR SISWA
}

\author{
THE EXPLORATION OF METACOGNITION OF \\ MATHEMATICAL PROBLEM SOLVING REVIEWED BY \\ STUDENTS' LEARNING STYLES
}

\author{
Nurjannah \\ Institut Agama Islam Muhammadiyah Sinjai \\ Nurjannah310807@gmail.com
}

\begin{abstract}
Abstrak
Penelitian ini adalah penelitian kualitatif yang bertujuan untuk menggambarkan hasil eksplorasi metakognisi siswa terhadap pemecahan masalah matematika ditinjau dari gaya belajar (visual, auditorial, dan kinestetik). Subjek penelitian adalah tiga orang siswa kelas VI SD Negeri 286 Pasaka masing-masing bergaya belajar visual, auditorial dan kinestetik, berjenis kelamin perempuan, kemampuan matematika relatif sama, dan komunikasi baik. Metode pengumpulan datanya adalah metode tugas dan wawancara. Hasil penelitian menunjukkan bahwa tidak terdapat perbedaan mendasar antara aktivitas metakognisi ketiga subjek pada tahap pertama dan kedua. Aktivitasnya berupa membaca soal dengan seksama untuk mengetahui ide pokok soal dan mengorganisasikan ide pokok tersebut dengan menuliskannya pada lembar kerja kemudian mentransformasi pengetahuan ke dalam bentuk gambar. Perbedaannya hanya terletak pada tahap ketiga yakni siswa visual dan kinestetik menjawab soal dengan jelas langkah demi langkahnya, siswa kinestetik menjawab soal dengan sangat runtut dan penuh dengan penjabaran sehingga jawabannya panjang dan jelas, sedangkan siswa auditorial menjawab soal dengan jawaban singkat.
\end{abstract}

Kata Kunci: Metakognisi, Visual, Auditorial, Kinestetik.

\section{Abstract}

This study was qualitative research that aimed at describing the results of the exploration of students' metacognisis on solving mathematical problems in terms of learning styles (visual, auditory, and kinesthetic). The subject of this study consisted of three students of grade sixth in 286 Pasaka Elementary School who had a visual learning style, auditory learning style and kinesthetic learning style. All of them were female sex with relatively similar mathematical abilities, and good communication skills. The data collected thorough assignment and interview. Based on the results of this study, it was found that basically there were no fundamental differences between the students' metacognition activities of visual, auditorial and kinesthetic in the first and second stages. Their activities included understanding questions by carefully reading questions to find out the core or main idea of the problem and organizing the main ideas in the questions through the work written on the worksheet then transforming knowledge or knowledge based on the understanding gained in the form of images. The difference was found only in the third stage of metacognitive activity Visual and kinesthetic students answered the questions with standards and clearly step by step, kinesthetic students answered the questions very closely and were full of translation so the answers were complete and clear while auditory students only answered the questions with short answers.

Keywords: Metacognition, Visual, Auditory, Kinesthetic. 


\section{Pendahuluan}

Pada umumnya matematika dipandang sebagai bidang studi yang kaku, simbolik dan jauh dari realita kehidupan sehari-hari. Pandangan tersebut berakibat pada adanya asumsi bahwa untuk mempelajari matematika, seorang siswa harus berfikir serius, abstrak, dan selalu menghapal rumus. Oleh karena itu, tidak jarang ada anggapan bahwa mata pelajaran matematika merupakan mata pelajaran yang sulit, sukar dipahami, dan membosankan bahkan bagi sebagian siswa menganggap matematika merupakan hal yang menakutkan, sehingga mereka cenderung menghindari mata pelajaran itu (Saefudin, 2012).

Fenomena ini terus berlanjut di setiap jenjangnya, yang membuat rasa ketidaktahuan siswa semakin besar dan semakin membuat mata pelajaran matematika tidak berarti di mata mereka. Kondisi ini, menyebabkan pelajaran matematika menjadi semakin tidak disenangi, tidak diperdulikan dan bahkan diabaikan, sehingga prestasi belajar matematika khususnya pada jenjang Sekolah Dasar secara umum adalah rendah (Karim, 2011).

Diantara faktor yang menyebabkan rendahnya prestasi belajar matematika bagi siswa adalah guru (Indrawati, 2006). Gaya mengajar dan strategi penyampaian bahan pelajaran yang dipilih seorang guru sangat menentukan keberhasilan pembelajaran matematika. Selain dianggap sulit, mata pelajaran matematika juga dianggap tidak menyenangkan, hal ini wajar terjadi karena dalam matematika objek dasar yang dipelajari adalah abstrak, sifat abstrak objek matematika tersebut tetap ada pada matematika sekolah (matematika yang diajarkan di sekolah). Melalui pemilihan metode, strategi mengajar, dan pendekatan yang tepat, guru dapat membantu mengurangi sifat abstrak dari objek Matematika (Johar, R., \& Hanum, 2016).

Penggunaan metode, strategi mengajar dan pendekatan oleh guru sangat menentukan kegiatan belajar siswa, serta penggunaan alat bantu peraga pelajaran dan media pembelajaran yang ada (Wibowo, 2012). Metode dan pendekatan pengajaran matematika sangat banyak meliputi metode ceramah, demonstrasi, tanya jawab, pemberian tugas, diskusi, inquiry dan lain-lain. Penggunaan metode-metode tersebut disesuaikan dengan materi yang akan disampaikan, karakteristik siswa, serta keberadaan lingkungan tempat siswa belajar (Rahmiati \& Pianda, 2018).

Namun, selain hal tersebut, faktor dalam diri siswa juga memiliki peranan penting dalam prestasi belajar (Siagian, 2015). Jika guru telah menggunakan metode yang cocok dengan materi yang diajarkan tetapi siswa masih belum mengerti materi yang diajarkan, sangat memungkinkan bahwa hal itu terjadi karena kurangnya kesadaran/kemauan siswa untuk mempelajari materi yang diajarkan atau dengan kata lain perkembangan kognitif siswa tersebut tidak berkembang pesat.

Flavell dalam (Postholm, 2016) mendefinisikan metakognisi sebagai kemampuan untuk memahami dan memantau berpikir diri sendiri dan asumsi serta implikasi kegiatan seseorang. Pendapat ini menekankan metakognisi sebagai kemampuan untuk memahami dan memantau kegiatan berpikir, sehingga proses metakognisi tiap-tiap orang akan berbeda menurut kemampuannya.

Metakognitif inilah yang dibutuhkan siswa untuk mengontrol aspek kognitifnya sehingga ketika siswa tersebut mendapatkan materi dari guru, maka materi itu akan mudah diserap (Amir, 2018). Jika hal tersebut terjadi, maka kecerdasan siswa akan terasah sehingga secara tidak langsung akan meningkatkan prestasi belajar siswa tersebut (Iskandar, 2016). 
Kemampuan metakognitif merupakan bagian dari apa yang disebut "proses eksekutif" atau "strategi metakognitif" (Warouw, 2009). Kemampuan metakognitif ini meliputi aktivitas seperti perhatian, persepsi, orientasi/monitoring pengertian persyaratan tugas, merencanakan langkah-langkah yang diambil untuk proses tugas, merespon/mengecek dan mengatur proses kognitif jika terjadi kegagalan, dan mengevaluasi hasil proses. Kemampuan metakognitif sebagai bagian dari proses pengaturan diri, kemampuan mengontrol proses berpikir diri sendiri ada dalam tiap tahapan dalam pemecahan masalah (Gunawan, \& Palupi, 2016). Pada tiap tahap (tahap orientasi, tahap organisasi, tahap eksekusi, dan tahap verifikasi) dalam menyelesaikan masalah siswa harus memonitor berpikirnya sekaligus membuat keputusan-keputusan dalam melaksanakan tahapan yang dipilihnya itu agar masalah dapat terselesaikan dengan baik bahkan pada tahap akhir, siswa harus mempertanyakan kembali atas jawaban yang dibuatnya apakah jawabannya benar-benar telah sesuai dan apakah memungkinkan ada cara lain yang lebih efektif dalam menyelesaikan masalah yang diberikan (Putri \& Tayeb, 2017).

Istilah metakognisi dalam dunia pendidikan pada waktu terakhir ini telah cukup luas digunakan, antara lain (Schoenfeld, 1992) mengartikan sebagai pemikiran tentang pemikiran kita sendiri yang merupakan interaksi antara tiga aspek penting yaitu: pengetahuan tentang proses berpikir kita sendiri, pengontrolan atau pengaturan diri, serta keyakinan dan intuisi, atau menurut pendapat Gama dalam (Mokos, 2013) yaitu mengoptimalkan hasil belajar yang dapat dicapai oleh siswa. Pada prinsipnya usaha melibatkan metakognisi dalam berbagai kegiatan belajar diharapkan memberi manfaat untuk meningkatkan kualitas belajar yang dilaksanakan.

Bila diperhatikan beberapa pendapat ahli, tampak bahwa tidak terdapat kesepakatan tentang definisi metakognisi secara formal, disebabkan banyaknya jenis pengetahuan dan proses berbeda masuk dalam istilah metakognisi, namun secara umum terdapat benang merah yang dapat ditarik untuk menghubungkan berbagai pendapat tersebut. Gambaran tentang perbedaan tersebut antara lain ditunjukkan oleh perbedaan pandangan antara dua orang pelopor studi tentang metakognisi yaitu Flavell dan Brown.

Sementara itu, Brown dalam (Gurat, 2016) mendefinisikan metakognisi sebagai suatu kesadaran terhadap aktivitas kognisi diri sendiri, metode yang digunakan untuk mengatur proses kognisi diri sendiri dan suatu penguasaan terhadap bagaimana mengarahkan, merencanakan, dan memantau aktivitas kognitif. Pendapat Brown ini menekankan metakognisi sebagai kesadaran terhadap aktivitas kognisi, dalam hal ini metakognisi berkaitan dengan bagaimana seseorang menyadari proses berpikirnya. Kesadaran tersebut akan terwujud pada cara seseorang mengatur dan mengelola aktivitas berpikir yang dilakukannya.

Menurut Gama dalam (Mokos, 2013) ada 3 strategi metakognitif yang dapat dikembangkan untuk meraih kesuksesan belajar siswa, diantaranya: 1) Tahap proses sadar belajar yang meliputi proses untuk menetapkan tujuan belajar, mempertimbangkan sumber belajar yang akan dan dapat diakses, menentukan bagaimana kinerja terbaik siswa yang akan dievaluasi, mempertimbangkan tingkat motivasi belajar, serta menentukan tingkat kesulitan belajar yang dialami siswa; 2) Tahap merencanakan belajar, meliputi proses memperkirakan waktu yang dibutuhkan untuk menyelesaikan tugas belajar yaitu merencanakan waktu belajar dalam bentuk jadwal serta menentukan skala prioritas dalam belajar, mengorganisasikan materi pelajaran, mengambil langkah-langkah yang sesuai untuk belajar dengan menggunakan berbagai strategi belajar; 3) Tahap monitoring dan refleksi belajar yaitu merefleksikan 
proses belajar, memantau proses belajar melalui pertanyaan dan tes diri serta menjaga konsentrasi dan motivasi tinggi dalam belajar.

Kognisi dan metakognisi pada dasarnya merupakan suatu rangkaian dari aktivitas berpikir yang dilakukan manusia. Ketika membicarakan pengembangan metakognisi, sebenarnya tidak terlepas dari membicarakan pengembangan kognisi itu sendiri, sehingga tidak berlebihan bila dikatakan bahwa kognisi dan metakognisi merupakan satu rangkaian yang tidak dapat dipisahkan. (Panaoura, A., Philippou, G. \& Christou, 2001) mengemukakan bahwa pengembangan metakognisi bukan merupakan proses yang bersifat automatis, tetapi merupakan hasil dari proses pengembangan yang panjang dari sistem kognitif.

Istilah kognisi cukup banyak digunakan khususnya berkaitan dengan pemrosesan informasi. Menurut Niesser istilah kognisi mengacu pada seluruh proses dimana input sensorik diubah, dikurangi, dimaknai, disimpan, diambil kembali, dan digunakan (Widadah, 2013). Dengan demikian, kognisi dalam hal ini berkaitan dengan cara seseorang memperoleh dan memproses informasi, menyimpan informasi, dan memanggilnya kembali untuk digunakan pada kegiatan belajar atau pemecahan masalah.

Secara sederhana, metakognisi dipahami sebagai berpikir tentang berpikir atau kognisi tentang kognisi seseorang, atau dapat dipandang bahwa metakognisi adalah kognisi pada tingkatan kedua. Pemahaman ini sejalan dengan pandangan Gama (Mokos. E, 2013), bahwa metakognisi adalah suatu bentuk dari kognisi, tingkatan kedua atau lebih tinggi dari proses berpikir yang meliputi kontrol aktif atas proses kognisi,

Berdasarkan model metakognisi oleh (Flavell, 1976) menyatakan bahwa metakognisi dan kognisi berbeda dalam isi dan fungsinya, tetapi mirip dalam bentuk dan kualitasnya. Dengan demikian metakognisi dan kognisi hanya dapat dibedakan dengan memperhatikan dua karakteristik dasarnya yaitu isi dan fungsi. a) Isi dari metakognisi adalah pengetahuan, keterampilan, dan kesadaran terhadap kognisi, sedangkan isi kognisi adalah hal-hal yang ada dalam dunia nyata atau dalam gambaran mental, b) Fungsi kognisi adalah untuk memecahkan masalah, sedangkan fungsi metakognisi adalah untuk mengatur aktivitas kognisi seseorang dalam memecahkan masalah atau melaksanakan suatu tugas.

Tabel 1. Kaitan Antara Kognisi dengan Metakognisi

\begin{tabular}{clrlr}
\hline & \multicolumn{2}{c}{ Isi } & \multicolumn{2}{c}{ Fungsi } \\
\hline Kognisi & $\begin{array}{l}\text { Hal-hal yang ada di dunia } \\
\text { nyata atau gambaran } \\
\text { mental }\end{array}$ & & \\
& Pengetahuan, & & Mengatur & aktivitas \\
& keterampilan, & dan & kognisi & dalam \\
kesadaran & terhadap & memecahkan masalah \\
& kognisi & & & \\
\hline
\end{tabular}

Jadi jelas bahwa terdapat keterkaitan yang sangat erat antara kognisi dengan metakognisi, dan keduanya merupakan satu rangkaian tidak terpisahkan. Usaha meningkatkan kemampuan kognisi seseorang, perlu didukung oleh peningkatan kemampuan metakognisi, demikian pula sebaliknya. Pada penerapannya dalam kegiatan belajar atau pemecahan masalah, proses kognisi dan metakognisi dapat berlangsung secara bersamaan atau beriringan, yang saling menunjang satu sama lain. 
Hal yang juga erat kaitannya dengan metakognisi adalah kemampuan pemecahan masalah. (Woolfolk, 2008) memberikan definisi masalah sebagai suatu situasi yang mana seseorang mencoba untuk mencapai tujuan tertentu dan harus menemukan cara untuk menyelesaikannya. Sementara menyatakan bahwa masalah adalah suatu situasi atau kondisi (dapat berupa pertanyaan/isu/soal) yang disadari dan memerlukan sesuatu tindakan penyelesaian, serta tidak segera tersedia cara untuk menguasai situasi itu. Sedangkan Bell (Rofiki, 2012) menyatakan bahwa situasi merupakan masalah bagi seseorang jika ia menyadari keberadaan situasi tersebut, mengakui bahwa hal itu memerlukan tindakan dan tidak segera dapat menemukan penyelesaiannya. Pengertian "tidak segera" dalam hal ini yaitu pada saat situasi tersebut muncul, diperlukan suatu usaha untuk mendapatkan cara yang dapat digunakan untuk mengatasinya.

Jadi yang dimaksud dengan masalah adalah suatu situasi yang disadari yang dihadapi oleh seseorang yang memerlukan penyelesaian tetapi tidak menggunakan prosedur rutin atau tidak tahu secara langsung apa yang harus dikerjakan untuk menyelesaikannya.

Dalam pembelajaran matematika, pertanyaan atau masalah yang dihadapkan kepada siswa biasanya dalam bentuk soal. Namun tidak semua soal matematika merupakan masalah. Menurut Sudarman (Rofiki, 2012) jika kita menghadapi suatu soal matematika, maka ada beberapa hal yang mungkin terjadi yaitu a) langsung mengetahui atau mempunyai gambaran tentang penyelesaiannya tetapi tidak berkeinginan untuk menyelesaikan soal tersebut; b) mempunyai gambaran tentang penyelesaiannya dan berkeinginan untuk menyelesaikannya; c) tidak mempunyai gambaran tentang penyelesaiannya akan tetapi berkeinginan untuk menyelesaikan soal-soal tersebut; dan d) tidak mempunyai gambaran tentang penyelesaiannya dan tidak berkeinginan untuk menyelesaikan soal tersebut. Apabila seorang siswa berada pada kemungkinan (c) maka dikatakan soal matematika itu masalah baginya dan dibutuhkan langkah-langkah untuk memecahkan masalah tersebut.

(Polya, 2014) membagi langkah pemecahan masalah menjadi 4 tahap, yaitu: a) memahami masalah, pemahaman terhadap masalah dapat diketahui dengan menyatakan masalah yang akan dipecahkan dengan kalimat yang lain; b) membuat rencana, ide rencana penyelesaian dapat diperoleh dengan memikirkan penyelesaian untuk masalah yang serupa namun lebih sederhana dan memikirkan apakah langkah penyelesaian tersebut dapat diterapkan pada masalah yang sedang dihadapi sekarang; c) melaksanakan rencana, setelah rencana penyelesaian ditentukan, selanjutnya yaitu menggunakan rencana yang telah ditentukan tersebut untuk menyelesaikan masalah yang dihadapi; dan d) memeriksa kembali, dengan memeriksa kembali solusi yang komplit, mempertimbangkan dan menguji kembali hasil yang diperoleh dan langkahlangkah yang telah dilakukan, maka siswa tersebut telah menggabungkan pengetahuannya dan membangun kemampuannya dalam memecahkan masalah.

Berangkat dari gagasan (Polya, 2014) tentang langkah-langkah pemecahan masalah, dapat dikatakan bahwa semua langkah yang dikemukakan mengarahkan kepada kesadaran dan pengaturan siswa terhadap proses yang dilaksanakan untuk memperoleh solusi yang tepat. (Polya, 2014) menyebutkan pemikirannya tersebut sebagai "berpikir tentang proses" (thinking about the process) dalam kaitannya dengan kesuksesan pemecahan masalah.

Bila dicermati langkah-langkah yang dikembangkan oleh (Polya, 2014) tampak bahwa pemecahan masalah dilaksanakan berdasarkan pada adanya pengetahuan tentang kognisi (knowledge about cognition), serta pengaturan kognisi (regulation of cognition). 
Seperti telah dibahas pada bagian sebelumnya, kedua unsur tersebut merupakan komponen dari metakognisi.

(Brown, 1987) mengemukakan keterampilan atau kemampuan metakognisi yang esensial bagi setiap pemecah masalah yang efisien meliputi kemampuan dalam: a) perencanaan (planning), meliputi pendugaan hasil, dan penjadwalan strategi, b) pemantauan (monitoring), meliputi pengujian, perevisian, dan penjadwalan ulang strategi yang dilakukan, dan c) pemeriksaan (checking), meliputi evaluasi hasil dari pelaksanaan suatu strategi berdasarkan kriteria efisiensi dan efektivitas.

Apabila siswa menggunakan kemampuan metakognisinya dengan baik, maka siswa tersebut akan mudah dalam memecahkan masalah matematika. Selain kemampuan metakognisi, hal yang diduga dapat memberikan pengaruh bagi siswa dalam memecahkan masalah ada gaya belajar yang dimiliki siswa. Diduga bahwa gaya belajar siswa yang berbeda dapat menimbulkan aktivitas metakognisi yang berbeda pula. (De Porter, B. \& Hernacki, 2015) mengemukakan bahwa terdapat tiga modalitas (type) dalam gaya belajar yaitu visual, auditorial, dan kinestetik. Gaya belajar visual menitikberatkan pada indra penglihatan sehingga peserta didik yang memiliki gaya belajar ini lebih cenderung menyukai proses pembelajaran yang melibatkan gambar dan segala sesuatu yang berhubungan dengan penglihatan. Gaya belajar auditorial atau lebih dikenal dengan gaya belajar auditorial, yakni gaya belajar yang menggunakan indra pendengaran. Sedangkan gaya belajar kinestetik yakni gaya belajar yang mengharuskan adanya gerakan atau praktek saat proses belajar mengajar berlangsung (Sari, 2014).

Berdasarkan hal-hal sebagaimana peneliti kemukakan di atas, maka peneliti akan melakukan penelitian tentang eksplorasi metakognisi terhadap pemecahan masalah matematika ditinjau dari gaya belajar siswa.

\section{Metode Penelitian}

Penelitian ini merupakan penelitian eksploratif dengan pendekatan kualitatif. Subjek penelitian ini terdiri dari tiga orang siswa kelas VI di SD Negeri 286 Pasaka masing-masing memiliki gaya belajar visual, gaya belajar auditorial dan gaya belajar kinestetik. Untuk menentukan subjek dengan gaya belajar visual, gaya belajar auditorial dan gaya belajar kinestetik, maka diberikan angket gaya belajar yang kemudian dianalisis sehingga terpilihlah subjek penelitian yang memenuhi kriteria yakni bergaya belajar visual, auditorial dan kinestetik. Selain kriteria tersebut, ketiga subjek penelitian juga harus berjenis kelamin perempuan dengan kemampuan matematika relatif sama, dan berkemampuan komunikasi baik.

Metode pengumpulan data yang digunakan dalam penelitian ini ada dua, yakni metode tugas dan wawancara. Masing-masing subjek penelitian diberikan Tugas berupa soal-soal pemecahan masalah matematika untuk diselesaikan dalam waktu kurang dari enam puluh menit kemudian dilakukan wawancara yang berkaitan dengan tugas yang telah diselesaikan. Tugas Pemecahan Masalah Matematika diberikan sebanyak dua kali pada waktu yang berbeda untuk melihat kemampuan masing-masing subjek penelitian.

Data yang telah diperoleh dari wawancara perlu dicek validitasnya. Teknik yang digunakan untuk mengecek validitas data dalam penelitian ini adalah teknik triangulasi waktu yakni pengecekan validitas terhadap data pada wawancara pertama dengan data pada wawancara kedua. 


\section{Hasil dan Pembahasan}

\subsection{Metakognisi Siswa dalam Memecahkan Masalah Matematika Siswa dengan Gaya Belajar Visual}

Aktivitas metakognisi siswa dalam memecahkan masalah dengan gaya belajar visual pada tahap pertama yaitu siswa memahami soal dengan membaca soal dengan seksama untuk mengetahui inti atau ide pokok soal. Hal ini bertujuan untuk memperoleh informasi yang dibutuhkan untuk menemukan cara terbaik dalam menyelesaikan soal atau masalah yang diberikan. Tahap perencanaan ini dilakukan untuk mengidentifikasi hal-hal pokok yang termuat dalam suatu soal sehingga siswa dapat memutuskan penyelesaian yang tepat.

Aktivitas metakognisi siswa dalam memecahkan masalah dengan gaya belajar visual pada tahap kedua yaitu melihat soal kemudian mengingat materi yang berhubungan dengan soal serta menyebutkan materi pokok permasalahan kemudian memilih ide pokok soal. Hal in terlihat dengan mampunya siswa menyebutkan hal yang diketahui dan tujuan/maksud soal. Memilih ide pokok merupakan strategi dalam menyesuaikan pengetahuan yang dimilki dengan masalah yang dihadapi.

Aktivitas metakognisi siswa dalam memecahkan masalah dengan gaya belajar visual pada tahap ketiga yaitu siswa menggunakan pengetahuan prosedural yang dimilkinya untuk mengungkapakan langkah demi langkah pengerjaan yang dilakukan untuk melakukan pengecekan atas metode yang dipilih. Hal ini dilakukan sambil melihat soal yang diberikan serta terkadang menunjuk bagian-bagian soal. Hasil jawabannya terbilang standar dan jelas langkah demi lengkahnya.

\subsection{Metakognisi Siswa dalam Memecahkan Masalah Matematika Siswa dengan Gaya Belajar Auditorial}

Aktivitas metakognisi siswa dalam memecahkan masalah dengan gaya belajar auditorial pada tahap pertama yaitu siswa memahami soal dengan membaca soal dengan seksama untuk mengetahui inti atau ide pokok soal. Hal ini bertujuan untuk memperoleh informasi yang dibutuhkan untuk menemukan cara terbaik dalam menyelesaikan soal atau masalah yang diberikan. Tahap perencanaan ini dilakukan untuk mengidentifikasi hal-hal pokok yang termuat dalam suatu soal sehingga siswa dapat memutuskan penyelesaian yang tepat.

Aktivitas metakognisi siswa dalam memecahkan masalah dengan gaya belajar auditorial pada tahap kedua yaitu mengorganisasikan ide pokok dalam soal yang dipahaminya melalui pekerjaan yang dituliskan dalam lembar kerja kemudian mentransformasi pengetahuan atau ilmu berdasarkan pemahaman yang didapat ke dalam bentuk gambar. Siswa juga menyebutkan hal yang diketahui dan tujuan/maksud soal. Kemudian, memilih ide pokok merupakan strategi dalam menyesuaikan pengetahuan yang dimilki dengan masalah yang dihadapi.

Aktivitas metakognisi siswa dalam memecahkan masalah dengan gaya belajar auditorial pada tahap ketiga yaitu siswa menyatakan keyakinan diri terhadap pemahaman yang dimiliki kemudian menyelesaikan masalah dengan jawaban singkat sambil melihat soal yang diberikan.

\subsection{Metakognisi Siswa dalam Memecahkan Masalah Matematika Siswa dengan Gaya Belajar Kinestetik}

Aktivitas metakognisi siswa dalam memecahkan masalah dengan gaya belajar kinestetik pada tahap pertama yaitu siswa memahami soal dengan cara membaca 
keseluruhan yang terlihat dari pengucapan yang terdengar oleh telinga. Hal ini dapat diartikan membaca soal atau masalah bertujuan memperoleh informasi yang dibutuhkan untuk menemukan cara penyelesaian soal yang tepat dan benar. Untuk mencapai tujuan yang diinginkan maka dibutuhkan suatu mekanisme atau strategi membaca agar didapatkan pemahaman yang kuat dan menyeluruh pada soal yang diberikan.

Aktivitas metakognisi siswa dalam memecahkan masalah dengan gaya belajar kinestetik pada tahap kedua yaitu melakukan kegiatan berupa mengingat materi yang berhubungan dengan melihat soal dan menyebutkan materi yang berhubungan, kemudian siswa memilih ide pokok soal dengan menuliskan hal-hal yang diketahui dan ditanyakan untuk menyelesaiakan soal.

Aktivitas metakognisi siswa dalam memecahkan masalah dengan gaya belajar kinestetik pada tahap ketiga yaitu siswa menggunakan pengetahuan prosedural yang dimilki terhadap soal dengan mengungkapakan langkah-langkah pengerjaan yang akan dilakukan dengan melihat soal yang diberikan sambil menunjuk bagian-bagian soal. Hasil pemecahan masalahnya terlihat sangat runtut dan penuh dengan penjabaran sehingga jawabannya panjang dan jelas.

Tabel 2. Perbandingan Metakognisi Siswa dalam Memecahkan Masalah Matematika pada Masing-masing Gaya Belajar

\begin{tabular}{|c|c|c|c|}
\hline \multirow{2}{*}{$\begin{array}{c}\text { Tahapan } \\
\text { Metakognisi } \\
\text { dalam } \\
\text { Pemecahan } \\
\text { Masalah }\end{array}$} & \multicolumn{3}{|c|}{ Gaya Belajar } \\
\hline & Visual & Auditorial & Kinestetik \\
\hline $\begin{array}{c}\text { Perencanaan } \\
\text { (Planning) }\end{array}$ & $\begin{array}{lr}\text { Membaca } & \text { soal } \\
\text { dengan } & \text { seksama } \\
\text { untuk mengetahui } \\
\text { inti atau ide pokok } \\
\text { soal. }\end{array}$ & $\begin{array}{lr}\text { Membaca } & \text { soal } \\
\text { dengan } & \text { seksama } \\
\text { untuk mengetahui } \\
\text { inti atau ide pokok } \\
\text { soal. }\end{array}$ & $\begin{array}{l}\text { Membaca soal } \\
\text { secara keseluruhan } \\
\text { yang terlihat dari } \\
\text { pengucapan yang } \\
\text { terdengar oleh } \\
\text { telinga. }\end{array}$ \\
\hline $\begin{array}{l}\text { Pemantauan } \\
\text { (Monitoring) }\end{array}$ & $\begin{array}{l}\text { Melihat } \\
\text { kemudian } \\
\text { mengingat materi } \\
\text { yang berhubungan } \\
\text { dengan soal serta } \\
\text { menyebutkan } \\
\text { materi pokok } \\
\text { permasalahan } \\
\text { kemudian memilih } \\
\text { ide pokok soal, } \\
\text { menyebutkan hal } \\
\text { yang diketahui dan } \\
\text { tujuan/maksud soal. }\end{array}$ & $\begin{array}{l}\text { Mengorganisasikan } \\
\text { ide pokok dalam } \\
\text { soal yang } \\
\text { dipahaminya } \\
\text { melalui pekerjaan } \\
\text { yang dituliskan } \\
\text { dalam lembar kerja } \\
\text { kemudian } \\
\text { mentransformasi } \\
\text { pengetahuan atau } \\
\text { ilmu berdasarkan } \\
\text { pemahaman yang } \\
\text { didapat ke dalam } \\
\text { bentuk gambar, } \\
\text { memilih ide pokok } \\
\text { soal dengan } \\
\text { menuliskan hal-hal } \\
\text { yang diketahui dan }\end{array}$ & $\begin{array}{l}\text { Melakukan } \\
\text { kegiatan berupa } \\
\text { mengingat materi } \\
\text { yang berhubungan } \\
\text { dengan melihat } \\
\text { soal dan } \\
\text { menyebutkan } \\
\text { materi yang } \\
\text { berhubungan, } \\
\text { kemudian siswa } \\
\text { memilih ide pokok } \\
\text { soal dengan } \\
\text { menuliskan hal-hal } \\
\text { yang diketahui dan } \\
\text { ditanyakan untuk } \\
\text { menyelesaiakan } \\
\text { soal. }\end{array}$ \\
\hline
\end{tabular}




\begin{tabular}{|c|c|c|c|}
\hline \multirow{3}{*}{$\begin{array}{c}\text { Tahapan } \\
\text { Metakognisi } \\
\text { dalam } \\
\text { Pemecahan } \\
\text { Masalah } \\
\end{array}$} & \multicolumn{3}{|c|}{ Gaya Belajar } \\
\hline & Visual & Auditorial & Kinestetik \\
\hline & & $\begin{array}{l}\text { ditanyakan untuk } \\
\text { menyelesaiakan } \\
\text { soal. }\end{array}$ & \\
\hline $\begin{array}{c}\text { Pengecekan } \\
\text { (Checking) }\end{array}$ & $\begin{array}{l}\text { Menggunakan } \\
\text { pengetahuan } \\
\text { prosedural yang } \\
\text { dimilkinya untuk } \\
\text { mengungkapakan } \\
\text { langkah demi } \\
\text { langkah pengerjaan } \\
\text { yang dilakukan } \\
\text { untuk melakukan } \\
\text { pengecekan atas } \\
\text { metode yang } \\
\text { dipilih. Hal ini } \\
\text { dilakukan sambil } \\
\text { melihat soal yang } \\
\text { diberikan serta } \\
\text { terkadang } \\
\text { menunjuk bagian- } \\
\text { bagian soal. Hasil } \\
\text { jawabannya } \\
\text { terbilang standar } \\
\text { dan jelas langkah } \\
\text { demi lengkahnya. }\end{array}$ & $\begin{array}{l}\text { Menyatakan } \\
\text { keyakinan diri } \\
\text { terhadap } \\
\text { pemahaman yang } \\
\text { dimiliki kemudian } \\
\text { menyelesaikan } \\
\text { masalah dengan } \\
\text { jawaban singkat } \\
\text { sambil melihat soal } \\
\text { yang diberikan. }\end{array}$ & $\begin{array}{l}\text { Menggunakan } \\
\text { pengetahuan } \\
\text { prosedural yang } \\
\text { dimilki terhadap } \\
\text { soal dengan } \\
\text { mengungkapakan } \\
\text { langkah-langkah } \\
\text { pengerjaan yang } \\
\text { akan dilakukan } \\
\text { dengan melihat } \\
\text { soal yang } \\
\text { diberikan sambil } \\
\text { menunjuk bagian- } \\
\text { bagian soal. Hasil } \\
\text { pemecahan } \\
\text { masalahnya } \\
\text { terlihat sangat } \\
\text { runtut dan penuh } \\
\text { dengan penjabaran } \\
\text { sehingga } \\
\text { jawabannya } \\
\text { panjang dan jelas. }\end{array}$ \\
\hline
\end{tabular}

\section{Kesimpulan}

Pada dasarnya tidak terdapat perbedaan yang mendasar antara aktivitas metakognisi yang dilakukan oleh siswa visual, auditorial dan kinestetik. Pada tahap pertama, siswa visual, auditorial dan kinestetik sama-sama memahami soal dengan membaca soal dengan seksama untuk mengetahui inti atau ide pokok soal. Tahap ini dilakukan untuk mengidentifikasi hal-hal pokok yang termuat dalam suatu soal sehingga siswa dapat memutuskan penyelesaian yang tepat. Pada tahap kedua, siswa visual, auditorial dan kinestetik sama-sama mengorganisasikan ide pokok dalam soal yang dipahaminya melalui pekerjaan yang dituliskan dalam lembar kerja kemudian mentransformasi pengetahuan atau ilmu berdasarkan pemahaman yang didapat ke dalam bentuk gambar. Siswa juga menyebutkan hal yang diketahui dan tujuan/maksud soal. Kemudian, memilih ide pokok merupakan strategi dalam menyesuaikan pengetahuan yang dimilki dengan masalah yang dihadapi. Perbedaannya hanya terletak pada tahap ketiga aktivitas metakognisi yakni siswa visual dan kinestetik menjawab soal dengan standar dan jelas langkah demi lengkahnya, siswa kinestetik menjawab soal dengan sangat runtut dan penuh dengan penjabaran sehingga jawabannya panjang dan jelas sedangkan siswa auditorial hanya menjawab soal dengan jawaban singkat. 


\section{Daftar Pustaka}

Amir, M. F. (2018). Pengembangan Perangkat Pembelajaran Berbasis Masalah Kontekstual untuk Meningkatkan Kemampuan Metakognisi Siswa Sekolah Dasar. Journal of Mathematics Education IKIP Veteran Semarang, 2(1), 117-128. Retrieved from http://e-journal.ivet.ac.id/index.php/matematika/article/view/538

Brown, A. (1987). Metacognition, Executive Control, Self-Regulation, and Other More Mysterious Mechanisms. Retrieved from https://www.cambridgeinternational.org/Images/272307-metacognition.pdf

De Porter, B. \& Hernacki, M. (2015). Quantum Learning. Membiasakan Belajar Nyaman dan Menyenangkan. Bandung: Alwiyah Abdurrahman Kaifa.

Flavell, J. H. (1976). Metacognitive Aspects of Problem Solving. The Nature of IItelligence, 231-235. Retrieved from http://www.sciepub.com/reference/146040

Gunawan, I., \& Palupi, A. R. (2016). Taksonomi Bloom-Revisi Ranah Kognitif: Kerangka Landasan untuk Pembelajaran, Pengajaran, dan Penilaian. Premiere Educandum: Jurnal Pendidikan Dasar Dan Pembelajaran, 2(2). Retrieved from http://e-journal.unipma.ac.id/index.php/PE/article/view/50

Indrawati, Y. (2006). Faktor-faktor yang Mempengaruhi Kinerja Guru Matematika dalam Pelaksanaan Kurikulum Berbasis Kompetensi (KBK) Pada Sekolah Menengah Atas Kota Palembang. Jurnal Manajemen \& Bisnis Sriwijaya, 4(7), 4158. Retrieved from http://www.infodiknas.com/wpcontent/uploads/2014/11/FAKTOR-FAKTOR-YANG-MEMPENGARUHIKINERJA-GURU-MATEMATIKA-DALAM-PELAKSANAAN-KURIKULUMBERBASIS-KOMPETENSI-KBK.pdf

Iskandar, S. M. (2016). Pendekatan Keterampilan Metakognitif dalam Pembelajaran Sains di Kelas. ERUDIO (Journal of Educational Innovation), 2(2), 13-20. Retrieved from http://erudio.ub.ac.id/index.php/erudio/article/view/151

Johar, R., \& Hanum, L. (2016). Strategi Belajar Mengajar. Sleman: Deepublish.

Karim, A. (2011). Penerapan Metode Penemuan Terbimbing dalam Pembelajaran Matematika untuk Meningkatkan Pemahaman Konsep dan Kemampuan Berpikir Kritis Siswa Sekolah Dasar. Jurnal Pendidikan Matematika, 1(1), 21-32. Retrieved from http://jurnal.upi.edu/file/3-Asrul_Karim.pdf

Melanie G. Gurat, C. T. M. J. (2016). Metacognitive Strategy Knowledge Use through Mathematical Problem Solving amongst Pre-service Teachers. American Journal of Educational Research, 4(2), 170-189. Retrieved from http://www.sciepub.com/reference/146035

Mokos. E. (2013). Elementary Students' Spontaneous Metacognitive Functions in Different Types of Mathematical Problems. REDIMAT- Journal of Research in Mathematics Education, 2(2), 242-267. Retrieved from https://www.google.com/url?sa=t\&rct=j\&q=\&esrc=s\&source=web\&cd=1\&cad=rja \&uact=8\&ved=2ahUKEwjJk5qd_4rjAhVLPI8KHcOHAdAQFjAAegQIABAC\&ur l=https\%3A\%2F\%2Fdialnet.unirioja.es\%2Fdescarga\%2Farticulo\%2F4779971.pdf \&usg=AOvVaw3xCHBqvGc2QQBYWZwtz8-g

Panaoura, A., Philippou, G. \& Christou, C. (2001). Young Pupils' Metacognitive Ability in Mathematics. European Research in Mathematics Education, 3, 1-9. Retrieved from https://www.google.com/url?sa=t\&rct=j\&q=\&esrc=s\&source=web\&cd=1\&cad=rja \&uact=8\&ved=2ahUKEwi2ruCXgovjAhWHLo8KHaE4C68QFjAAegQIBBAC\& url $=$ http $\% 3 \mathrm{~A} \% 2 \mathrm{~F} \% 2 \mathrm{Fciteseerx}$. ist.psu.edu $\% 2 \mathrm{Fviewdoc} \% 2 \mathrm{Fdownload} \% 3 \mathrm{Fdoi} \% 3$ 
D10.1.1.533.3255\%26rep\%3Drep1\%26type\%3Dpdf\&usg=AOvVaw2_ujNhglDKz IWkY2LvPzXd

Polya, G. (2014). How to solve it: A New Aspect of Mathematical Method. Retrieved from https://press.princeton.edu/titles/669.html

Postholm, M. B. (2016). Experienced Teachers Reflecting on Challenging Situations in School. Creative Education, 7(9), 1314-1327. Retrieved from https://www.scirp.org/(S(351jmbntvnsjt1aadkposzje))/reference/ReferencesPapers. aspx?ReferenceID $=1788877$

Putri, A. P., \& Tayeb, T. (2017). Kemampuan Metakognisi untuk Meningkatkan Keterampilan Pemecahan Masalah Matematika Siswa Kelas VIII B MTS Madani Alauddin Paopao Kabupaten Gowa. MaPan: Jurnal Matematika Dan Pembelajaran, 5(1). Retrieved from http://journal.uinalauddin.ac.id/index.php/Mapan/article/view/2825

Rahmiati, \& Pianda, D. (2018). Strategi dan Implementasi Pembelajaran Matematika di Depan Kelas. Suka Bumi, Jawa Barat: Jejak Publisher.

Rofiki, I. (2012). Profil Pemecahan Masalah Geometri Siswa Kelas Akselerasi SMP Ditinjau dari Tingkat Kemampuan Matematika. UNESA.

Saefudin, A. A. (2012). Pengembangan Kemampuan Berpikir Kreatif Siswa dalam Pembelajaran Matematika dengan Pendekatan Pendidikan Matematika Realistik Indonesia (PMRI). Jurnal Al Bidayah, 4(1). Retrieved from http://jurnal.albidayah.id/index.php/home/article/view/10

Sari, A. K. (2014). Analisis Karakteristik Gaya Belajar VAK (Visual, Auditorial, Kinestetik) Mahasiswa Pendidikan Informatika Angkatan 2014. Edutic-Scientific Journal of Informatics Education, 1(1). Retrieved from http://journal.trunojoyo.ac.id/edutic/article/view/395

Schoenfeld, A. (1992). Learning to Think Mathematically: Problem Solving, Metacognition, and Sense-making in Mathematics. Learning from Instraction, 334-370.

Retrieved

from https://www.researchgate.net/publication/289963462_Learning_to_think_mathema tically_Problem_solving_metacognition_and_sense_making_in_mathematics/dow nload

Siagian, R. E. F. (2015). Pengaruh Minat dan Kebiasaan Belajar Siswa Terhadap Prestasi Belajar Matematika. Jurnal Ilmiah Pendidikan MIPA, 2(2). Retrieved from http://journal.lppmunindra.ac.id/index.php/Formatif/article/view/93

Warouw, Z. W. M. (2009). Pengaruh Pembelajaran Metakognitif dalam Strategi Cooperative Script dan Reciprocal Teaching pada Kemampuan Akademik Berbeda terhadap Kemampuan dan Keterampilan Metakognitif, Berpikir Kritis, Hasil Belajar Biologi Siswa, serta Retensinya di SMP Negeri Man.

Wibowo, E. J. (2012). Media Pembelajaran Interaktif Matematika untuk Siswa Sekolah Dasar Kelas IV. Seruni-Seminar Riset Unggulan Nasional Informatika, 1(1). Retrieved from http://portal.ejurnal.net/index.php/seruni/article/view/1082

Widadah, S. (2013). Profil Metakognisi Siswa dalam Menyelesaikan Soal Sistem Persamaan Linear Dua Variabel Berdasarkan Gaya Kognitif. Jurnal Pendidikan Matematika STKIP PGRI Sidoarjo, 1(1), 13-24. Retrieved from https://www.google.com/url?sa=t\&rct=j\&q=\&esrc=s\&source=web\&cd=1\&cad=rja \&uact $=8 \&$ ved $=2$ ahUKEwi-

4Pr0g4vjAhWSknAKHU3GDq0QFjAAegQIAhAB\&url=https\%3A\%2F\%2Fwww .researchgate.net\%2Fpublication\%2F318967128_PROFIL_METAKOGNISI_SIS 
WA_DALAM_MENYELESAIKAN_SOAL_SISTEM_PERSAMAAN_LINEAR_ DUA_VARIABEL_BERDASARKAN_GAYA_KOGNITIF_METAKOGNISI\%2 527S_PROFILE_STUDENT_IN_SOLVE_EQUATION_SYSTEM_PROBLEM_L INEAR_TWO_VARIABLE_BASE\&usg=AOvVaw09XZ8ArvYSExQIpH6qUxxq Woolfolk, A. H. \& W. (2008). Psychology in Mathematics London. London: Pearson Longman. 